\title{
Experiential Learning And Management Education: Empirical Research And Implications For Practice In Higher Education In Slovenia
}

\author{
Sandra Penger, University of Ljubljana, Slovenia \\ Jana Žnidaršič, University of Ljubljana, Slovenia \\ Vlado Dimovski, University of Ljubljana, Slovenia
}

\begin{abstract}
Nowadays lecturers in higher education need an awareness of the experiential learning style preferences of students in order to develop and utilize effective and efficient teaching and pedagogical strategies and methods. The experiential learning styles literature has had a revival during last years, especially in the first decade of 21st century (Alban \& Metcalfe 2002; Duff \& Duffy, 2002; Kayes, 2003; Loo, 2004; Reynolds \& Vince, 2007; Cowen \& Kazamias, 2009). Upon reviewing the literature on experiential learning, the intense rate and growing interest is involved also in Slovenia, especially when analyzing the case of University of Ljubljana, Faculty of Economics (FELU; http://www.ef.uni-lj.si/en/) in Slovenia. In April 2010 FELU joined an elite group of institutions that have achieved business accreditation from AACSB International. Moreover, combined with EQUIS accreditation, FELU is ranked among 45 best business schools worldwide. The purpose of this paper is to offer a better insight into the experiential learning practices at FELU in order to develop appropriate teaching and pedagogical strategies for improving higher management education in Slovenia. The research objective of this study was to develop rather comprehensive inventory of experiential learning styles and methods, included both a descriptive and an exploratory perspective. In the theoretical part of the study the qualitative meta-analysis method was used to overview the literature background of the study. In the empirical part of the study the Principal Axis Factoring, using varimax rotation, was performed on the explanatory variables with primary goal of data reduction. The modified version of experiential learning style theory was used as research instrument in the questionnaire to determine Slovenian students' experiential learning styles. According to the research process we can summarize research thesis that matching students' experiential learning-style preferences with complementary course syllabus improve management education, academic achievements and student's attitudes toward learning.
\end{abstract}

Keywords: experiential learning; higher management education; factor analysis; Slovenia

\section{INTRODUCTION}

"Experiential learning is an approach that encourages collective and critical reflection as well as individual learning “(Vince \& Reynolds, 2007)

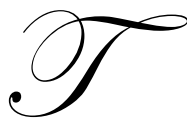

his paper examines the factors of the experiential learning practices at University of Ljubljana, Faculty of Economics (FELU; http://www.ef.uni-lj.si/en/) in order to develop appropriate teaching and pedagogical strategies for improving higher management education from the Slovenian perspective. The study introduces the experiential learning theories and styles from higher management education perspective. For the data analysis, factor analysis was employed (Malhotra, 2010). For our theoretical background 
we draw from experiential leering styles theories, theories of cognitive thinking, theories of learning modalities, theories of organizational learning, the Kolb's learning style inventory, the Dunn and Dunn's learning style, and Honey and Mumford's learning style questionnaire. For the educators in a higher education institution, the challenge is to provide meta-cognitive support for students, enabling them to reflect not just on what they learn but also how and why.

The concept of experiential learning is having a revival (Vince \& Reynolds, 2007), and has a broad meaning, in this research it is proposed and defined as a way of introducing concepts to students in depth, as well as representing complex work environments and allowing reflection on specific aspects of how and why we can and cannot learn. Experiential learning is an approach that is used to encourage students to become actively involved, and it is this activity that provides a means to generate "here and know" examples in order to reflect on the emotional and rational dynamics of managing and organizing. In view of that, learning style is defined as individual's preferential focus on different types of information, the different ways of perceiving the information, and the understanding the information (Li et al., 2008). Researchers have pointed out that students learn effectively in a harmonic environment and by using teaching aids which match the students' learning style preferences (Li et al., 2008). Although learning styles have been heavily researched (Duff \& Duffy, 2002; Lhori-Posey, 2003; Coffield et al., 2004; Reynold \& Vince, 2007; Welsh et al., 2007; Hornyak et al., 2007; Herbert \& Stenfors, 2007; Sievers, 2007; Hyde, 2007; Kayes A.B., 2007; Kayes D. C., 2007; Garcia et al., 2007; Demirbas \& Demirkan, 2007; Vince \& Reynolds; Armstrong \& Mahmud, 2008; Li et al., 2008), little is known about Slovenian students' experiential learning practices, especially in the field of higher education in Slovenia.

The aim of this study is to present, explore and discuss experiential learning practices and management education implications in Slovenia at FELU using factor analysis. For the purpose of the interpretation, each factor was composed of variables that loaded at 0.40 or higher on factor (Malhotra, 2010). Additionally, the intention of this research is to develop valid and reliable research recommendations for further research processes in practice and to set up assessment instruments as supportive mechanisms for the education's curriculums based on the experiential learning theory in higher education in Slovenia. The research thesis of this study is that matching students' experiential learning-style preferences with complementary course syllabus and instruction improve management education, academic achievement and student attitudes toward learning. Based on the experiential learning theories, the research instrument in the form of a questionnaire was developed intended to answer the research question indicating the development of a valid and reliable measurement instrument to match and determine student' learning styles preferences within educational institution.

This research paper has four main parts. First, it outlines the literature review and theoretical part of the study, summarizing experiential learning styles continuum and taxonomy. Additionally, it classifies various types of experiential learning styles theories and models according to the aim of the study. Second, it covers research framework and methodology, including data collection, sample characteristics, variables description, research instruments, and data analysis. Third, it tests the learning styles theories using factor analysis and summarizes results of the empirical part of the study. Finally, it discusses the results with research limitations and concludes by providing implications for management education.

\section{LITERATURE REVIEW}

The concept of experiential learning is embedded in different scholarly literatures, including psychology and organizational development (Armstrong \& Mahmud 2008; Allinson \& Hayes, 1990; Constantinidou \& Baker, 2002; Duff \& Duffy, 2002; Kayes, 2007; Kolb, 1976; Kolb, 1984; Sievers, 2007; Škerlavaj et al, 2010), higher management education (Alban-Metcalfe, 2002; Alkhasawneh et al, 2008; Champoux, 2007; Coffield et al, 2004; Coven \& Kazamias, 2009; Cuthbert, 2005; Dart et al, 2000; Demirbas et al, 2007; Ellinger, 2007; Entwistle, 1998; Herbert \& Stenfors, 2007; Kolb, 1999; Loo, 2004; Metallidou \& Platsidou, 2008; Peters et al, 2008), sociology (Dunn, 2001; Dunn \& Griggs, 2003; Welsh, 2007), leadership (Dimovski et al, 2009; Kayes, 2007; Zagoršek et al, 2009), management science (Argyris, 2007; Duff et al, 2008; Hyde, 2007; Kayes, 2002), organizational learning (Campo et al, 2008; Dimovski \& Škerlavaj, 2004; Dimovski et al, 2008; Škerlavaj \& Dimovski, 2006a, 2006b, 2007, Škerlavaj et al, 2008, 2010a; 2010b), information and technology systems (Dunn, 2003; Garcia et al., 2007; Tseng, 2008), and medicine science (Lhori-Posey, 2003; Li et al, 2008; Rourke et al, 2002). As such, it comes as no 
surprise that the concept of experiential is founded on a wide range of theoretical assumptions which should be viewed as complementary to each other in the understanding of higher management education (Honey \& Mumford, 1992; Reynolds \& Vince, 2007).

Figure 1 presents the continuum of experiential learning and management education theories and models based on the sequential meta-analysis. The taxonomy outlines the most influential research studies and research construct within experiential learning style categorization from 1960 till present, 2010. Upon reviewing the literature on experiential learning and management education growing interest is recognized. Consequently, eeducationalists introduced the concept of experiential based education process, which means crating a decentred classroom, with the instructor more of a collaborator, co-learner, mentor, and coacher than an authoritative figure dispensing factual data (Welsh et al, 2007).

According to Kolb (1984) experiential learning is the process whereby knowledge is created through the transformation of experience. Knowledge results from the combination of grasping and active experimentation of knowledge. Since team-based multidisciplinary experiences are becoming the norm of professional management education product in higher institutions, modeling those experiences in the classroom has great pedagogical value for academic achievements and student's outputs toward learning. In the current experiential learning literature (Reynolds \& Vince, 2009) two main perspectives for experiential learning styles in practice collide. In the first, Learning Style Theory perspective (Dunn \& Dunn, 2003) learners use visual, auditory, and kinesthetic modalities to receive and learn new information and experiences. Second perspective, called Learning Style Questionnaire Theory (Honey \& Mumford, 1992) has been designed to explore the relative strengths of four different learning modalities: activist, reflector, theorist and pragmatist.

\section{METHOD}

The overall research objective of the study is to determine the factors that govern the foundation of experiential based learning model for improving higher management education in Slovenia. The modified version of experiential learning style theory was used as research instruments in the questionnaire to determine Slovenian students' experiential learning styles and practices. The modification was chosen following the preliminary discussions with 3 experts from the field of research. The main criterion for modifying the questionnaires (i.e. reducing the number of questions from usually used questionnaires) was to reduce the number of variables to the level that allows statistical analysis with relatively small sample. The questions applied were those that, according to expert judgment, best described experiential learning characteristics. The research instrument was developed helping answer the research question indicating the conceptualization of an valid and reliable measurement instrument to match and determine student' experiential learning styles preferences within higher educational institution in Slovenia. The research question of the study was to test whether students from FELU follow theoretical assumptions of presented experiential learning style theory as it is conceptualized in the Figure 2. Classification of the experiential learning model used in the research integrates three main sensory receivers: visual, auditory, and kinesthetic to determine the dominant experiential learning style. Learners use all three modalities to receive and learn new experiences. While there is some evidence for modality specific strengths and weaknesses (Rourke et al., 2002), what has not been established is matching the instructional style to individual learning abilities.

The experiential learning styles were measured by interviewing 63 students during the course Economics of Education at FELU in summer semester 2008/2009. The convenience sampling was used for this purpose as, this being the first research on experiential learning styles in Slovenian higher educational system. Students were anonymously interviewed using paper questionnaires. The questionnaires take about 5 minutes to complete. This is significant since longer questionnaires may be less reliable due to responded fatigue (Malhotra, 2010). The questionnaire consisted of 12 variables, of which 2 were socio-demographic variables (gender and year of study) and the remaining 10 variables describing interviewees' learning attitudes (Figure 3). The five point Likert scale was used to characterize the level of agreement, ranging from: (1) disagree strongly, (2) disagree, (3) neutral, (4) agree, and (5) agree strongly. A total sum of 63 questionnaires were completed and returned immediately during the class. This represented a basis for factor analysis, where as a rough guideline there should be at least four to five times as many observations as there are variables (Neal, 2010). 
Figure 1: Experiential Learning and Management Education: Sequential Meta-Analysis

\begin{tabular}{|c|c|c|c|c|}
\hline \multicolumn{5}{|c|}{ - review of most influential theories and models of experiential learning styles and instruments } \\
\hline 1960 - & $1990-$ & $2002-2006$ & $2007-2008$ & Recent research: 2009-2010 \\
\hline$\downarrow$ & $\downarrow$ & $\downarrow$ & $\downarrow$ & $\downarrow$ \\
\hline $\begin{array}{l}\text { Myers - Briggs (1962) } \\
\text { Myers-Briggs Type Indicator } \\
\text { (MBTI) }\end{array}$ & $\begin{array}{l}\text { Conti \& Kolody (1990) } \\
\text { Self Knowledge Inventory } \\
\text { of Lifelong Learning } \\
\text { Skills (SKILLS) }\end{array}$ & $\begin{array}{l}\text { Alban \& Metcalfe (2002) } \\
\text { - disorder type behavior among } \\
\text { undergraduates }\end{array}$ & $\begin{array}{l}\text { Argyris (2007) } \\
\text { - double loop learning in a classroom setting }\end{array}$ & $\begin{array}{l}\text { Peterson, Rayner, \& Armstrong (2009) } \\
\text { - researching the psychology of cognitive } \\
\text { style and learning style }\end{array}$ \\
\hline $\begin{array}{l}\text { Paivio (1971) } \\
\text { Individual Difference Questionnaire } \\
\text { (IDQ) }\end{array}$ & $\begin{array}{l}\text { Epstein-Meier (1990) } \\
\text { Constructive Thinking } \\
\text { Inventory (CTI) }\end{array}$ & $\begin{array}{l}\text { Kayes }(2002) \\
\text { - experiential learning theory and its } \\
\text { critics: the role of experience in } \\
\text { management learning and education }\end{array}$ & $\begin{array}{l}\text { Champoux (2007) } \\
\text { - experiential learning in the on-line } \\
\text { environment }\end{array}$ & $\begin{array}{l}\text { Zagoršek, Dimovski \& Škerlavaj (2009) } \\
\text { - transactional and transformational } \\
\text { leadership impacts on organizational } \\
\text { learning. }\end{array}$ \\
\hline $\begin{array}{l}\text { Marks (1973) } \\
\text { Marks Vividness of Visual Imagery } \\
\text { Questionnaire Matching Familiar } \\
\text { Figures Test }\end{array}$ & $\begin{array}{l}\text { Miller (1991) } \\
\text { Personality typology: } \\
\text { cognitive, affective, } \\
\text { conative }\end{array}$ & $\begin{array}{l}\text { Duff \& Duffy (2002) } \\
\text { - Kolb's learning style questionnaire, } \\
\text { academic performance } \\
\text { - Honey \& Mumford's learning style } \\
\text { questionnaire }\end{array}$ & $\begin{array}{l}\text { Demirbas \& Demirkan (2007) } \\
\text { - learning styles and academic performance } \\
\text { - using Kolb's experiential learning theory } \\
\text { (ELT) }\end{array}$ & $\begin{array}{l}\text { Kappe, Boekholt, Rooyen, \& Flier } \\
\text { (2009) } \\
\text { - validity study of the learning style } \\
\text { questionnaire (LSQ) using multiple, } \\
\text { specific learning criteria }\end{array}$ \\
\hline $\begin{array}{l}\text { Grasha-Riechmann (1974) } \\
\text { Student Learning Style Scales } \\
\text { (SLSS) }\end{array}$ & $\begin{array}{l}\text { Herrmann (1995) } \\
\text { Brain Dominance } \\
\text { Instrument (BDI)revised } \\
\text { Inquiry Mode } \\
\text { Questionnaire }\end{array}$ & $\begin{array}{l}\text { Jackson (2002) } \\
\text { Learning Style Profiles (LSP) } \\
\text { Dunn \& Griggs (2003) } \\
\text { - Synthesis of the Dunn and Dunn } \\
\text { learning style model research }\end{array}$ & $\begin{array}{l}\text { Garcia, Amandi, Schiaffino \& Campo } \\
\text { (2007) } \\
\text { - detecting students' learning styles } \\
\text { - web based education }\end{array}$ & $\begin{array}{l}\text { Škerlavaj, Song \& Lee }(2010) \\
\text { - organizational learning culture } \\
\text { - innovative culture and innovations }\end{array}$ \\
\hline $\begin{array}{l}\text { Dunn and Dunn (1975, 1979, 1992, } \\
\text { 2003) VAK Learning Style Theory; } \\
\text { Learning Style Inventory (LSI); } \\
\text { Building Excellence Survey }\end{array}$ & $\begin{array}{l}\text { Allinson and Hayes } \\
(1996) \\
\text { Cognitive Style Index } \\
\text { (CSI) }\end{array}$ & $\begin{array}{l}\text { Lhori-Posey (2003) } \\
\text { - determining learning style preferences } \\
\text { of students }\end{array}$ & $\begin{array}{l}\text { Hornyak, Green \& Heppard (2007) } \\
\text { - implementing experiential learning }\end{array}$ & $\begin{array}{l}\text { Škerlavaj, Dimovski \& Desouza (2010) } \\
\text { - . intra organizational learning networks } \\
\text { - knowledge intensive organization }\end{array}$ \\
\hline $\begin{array}{l}\text { Kolb (1976, 1985, 1999) } \\
\text { Learning Style Inventory (LSI); } \\
\text { Revised; Learning Style InventoryI }\end{array}$ & $\begin{array}{l}\text { Cooper (1997) } \\
\text { Learning Styles ID }\end{array}$ & $\begin{array}{l}\text { Loo }(2004) \\
\text { - Kolb's learning style and learning } \\
\text { preferences }\end{array}$ & $\begin{array}{l}\text { Herbert \& Stenfors (2007) } \\
\text { - management education and experiential } \\
\text { learning methods }\end{array}$ & $\begin{array}{l}\text { Pretz, Totz \& Kaufman (2010) } \\
\text { - the effects of mood, cognitive style, and } \\
\text { cognitive ability on implicit learning }\end{array}$ \\
\hline $\begin{array}{l}\text { Hill (1976) } \\
\text { Cognitive Style Profile }\end{array}$ & $\begin{array}{l}\text { Harrison- Branson } \\
\text { (1998) } \\
\text { Apter (1998) } \\
\text { Motivation Style Profile } \\
\text { (MSP) }\end{array}$ & $\begin{array}{l}\text { Cuthbert (2005) } \\
\text { - student learning process: learning } \\
\text { styles or learning approaches } \\
\text { - learning situation } \\
\text { - teaching in higher education }\end{array}$ & $\begin{array}{l}\text { Kayes }(2007) \\
\text { - power and experience } \\
\text { - management education } \\
\text { - conversational learning }\end{array}$ & $\begin{array}{l}\text { Young }(2010) \\
\text { - validity of learning styles } \\
\text { - multicultural Investigation }\end{array}$ \\
\hline $\begin{array}{l}\text { Hunt (1978) } \\
\text { Paragraph Completion Method }\end{array}$ & $\begin{array}{l}\text { Entwistle (2000) } \\
\text { Approaches to Study } \\
\text { Inventory (ASI), Revised } \\
\text { Approaches to Study } \\
\text { Inventory (RASI }\end{array}$ & $\begin{array}{l}\text { Laureano-Cruces, Ramrez- } \\
\text { Rodrguez, de Arriaga \& Escarela- } \\
\text { Perez (2005) } \\
\text { - intelligent learning systems (ILSs) }\end{array}$ & $\begin{array}{l}\text { Reynolds \& Vince (2007) } \\
\text { - experiential learning and management } \\
\text { education }\end{array}$ & $\begin{array}{l}\text { Ortigosa, Paredes \& Rodriguez (2010) } \\
\text { - AH-questionnaire } \\
\text { - an adaptive hierarchical questionnaire for } \\
\text { learning styles }\end{array}$ \\
\hline $\begin{array}{l}\text { Honey and Mumford (1982) } \\
\text { Learning Style Questionnaire (LSQ) }\end{array}$ & $\begin{array}{l}\text { Hermanussen (2000) } \\
\text { Questionnaire Practice } \\
\text { Oriented Learning (QPL) }\end{array}$ & $\begin{array}{l}\text { Yannibelli, Godoy \& Amandi (2006) } \\
\text { - a genetic algorithm approach to } \\
\text { recognize students' learning styles } \\
\text { - computer-based educational systems }\end{array}$ & $\begin{array}{l}\text { Škerlavaj, Dimovski, Mrvar \& Pahor } \\
\text { (2008) } \\
\text { - intra - organizational learning networks } \\
\text { - knowledge intensive learning environments }\end{array}$ & $\begin{array}{l}\text { Arnold \& Paulus (2010) } \\
\text { - using a social networking site for } \\
\text { experiential learning: appropriating, } \\
\text { lurking, modeling and community building }\end{array}$ \\
\hline $\begin{array}{l}\text { Biggs (1987) } \\
\text { Study Process Questionnaire }\end{array}$ & $\begin{array}{l}\text { Dart et al (2000) } \\
\text { - students' conceptions of } \\
\text { learning }\end{array}$ & $\begin{array}{l}\text { Cuthbert (2006) } \\
\text { - student learning process in higher } \\
\text { education }\end{array}$ & $\begin{array}{l}\text { Škerlavaj \& Dimovski (2008) } \\
\text { - network perspective of intra-organizational } \\
\text { learning }\end{array}$ & $\begin{array}{l}\text { Koçakoğlu, Türkmen \& Solak (2010) } \\
\text { - motivational styles in problem based } \\
\text { learning }\end{array}$ \\
\hline
\end{tabular}

Source: Authors; adapted from the research papers and publications indicated in the figure, and: Coffield et al, 2004; Reynolds \& Vince, 2007; Penger \& Tekavčič, 2009. 
Figure 2: Classification of Experiential Based Learning Model

\begin{tabular}{|c|c|c|}
\hline \multicolumn{3}{|c|}{ Conceptualization of experiential learning style model used in research } \\
\hline $\begin{array}{c}\text { Seeing based experience } \\
\text { (visual receiver) }\end{array}$ & $\begin{array}{c}\text { Hearing based experience } \\
\text { (auditory receiver) }\end{array}$ & $\begin{array}{c}\begin{array}{c}\text { Doing based experience } \\
\text { (kinaesthetic receiver) }\end{array} \\
\end{array}$ \\
\hline Memorizes by creating mental images & Talks to self aloud & Enjoys doing activities \\
\hline Thinks in pi & Memorizes by steps in a sequence & Will try new things - likes to get \\
\hline Easily put off by visual distractions & Very aware of rhythm & involved Outgoing by nature; expresses \\
\hline Finds verbal instructions difficult & Easily distracted by noises & emotions by physical means \\
\hline Remembers faces & May have difficulty with & May find spelling difficult \\
\hline Strong on first impressions & instructions & Likes to solve problems by physically \\
\hline Enjoys usin & Remembers names & working through them \\
\hline Often a quick thinker & Enjoys music and the sounds of words & Is affected by touch or lack of it \\
\hline May focus on the 'big picture' and use & Enjoys talking and listening & Likes physical rewards \\
\hline advanced planning & May need time to think & Enjoys handling objects \\
\hline
\end{tabular}

Source: Authors; Adapted from Dunn \& Griggs, 2003; Dunn, 2001; Dunn, 2003.

Figure 3: Variables Description

\begin{tabular}{|c|c|c|c|}
\hline Vp1 & I prefer written instructions given by the lecturer. & Vp6 & $\begin{array}{l}\text { I can easily find the solution when given the spoken } \\
\text { instructions. }\end{array}$ \\
\hline Vp2 & I prefer spoken instructions given by the lecturer. & Vp7 & $\begin{array}{l}\text { Topics are best explained when presented on } \\
\text { paper/transparency/blackboard. }\end{array}$ \\
\hline Vp3 & $\begin{array}{l}\text { Asking questions, experiencing situations, and } \\
\text { discussing are the most effective way to learn the } \\
\text { topic. }\end{array}$ & Vp8 & $\begin{array}{l}\text { Practical examples and problem based-assignments are the } \\
\text { most effective learning tool. }\end{array}$ \\
\hline$V p 4 *$ & $\begin{array}{l}\text { Reading instructions can best help me learn the } \\
\text { topic. }\end{array}$ & Vp9 & $\begin{array}{l}\text { I learn most when doing practical simulation of presented } \\
\text { topics. }\end{array}$ \\
\hline$V p 5 *$ & $\begin{array}{l}\text { I prefer using electronic media (internet, email } \\
\text { etc.). }\end{array}$ & Vp10 & $\begin{array}{l}\text { I learn more easily when the lecturer has practical } \\
\text { experiences. }\end{array}$ \\
\hline
\end{tabular}

Source: Authors. *Variables that are in italic style were excluded from analysis because of inconsistency with other variables measuring similar approach.

\section{RESULTS}

Data were analyzed using the Statistical Package for the Social Sciences (SPSS 18.0). An alpha level of 0,05 was used as margin of statistical significance (Malhotra, 2010). The factor analysis using the Principal Axis Factoring method and varimax rotation was employed to extract experiential learning approaches. This method is also known as common factor analysis (Neal, 2010), where the factors are estimated based only on the common variance. Communalities are inserted in the diagonal of the correlation matrix. Factor analysis is a generic term for a family of statistical techniques concerned with the reduction of a set of observable variables in terms of a small number of latent factors. The Principal Axis Factoring method is appropriate when the primary concern is to identify the underlying dimensions and the common variance is of interest (Malhotra, 2010). An examination of the correlation matrix indicates that a considerable number of correlations exceeded 0.30 , and thus the matrix is suitable for factoring (Figure 4).

Figure 4: Correlation Matrix

Correlation Matrix

\begin{tabular}{|c|c|c|c|c|c|c|c|c|c|}
\hline & & Vp1 & Vp6 & $\overline{v p 2}$ & $\overline{v p} 7$ & Vp8 & $\overline{v p 9}$ & Vp3 & Vp10 \\
\hline \multirow[t]{8}{*}{ Correlation } & Vp1 & 1,000 &, 383 & .176 &,- 045 &,- 159 & .147 & .000 &,- 142 \\
\hline & Vp6 & .383 & 1,000 & .149 & .013 &, 032 & .114 & .041 &,- 021 \\
\hline & Vp2 & .176 & .149 & 1,000 & .446 & .075 & .040 &,- 131 &,- 059 \\
\hline & Vp7 &,- 045 & ,013 & .446 & 1,000 & .169 & .174 & .148 &, 062 \\
\hline & Vps &,- 159 & .032 & .075 & .169 & 1,000 & .254 & .434 &, 388 \\
\hline & $\vee p g$ & .147 & .114 & .040 & .174 & .254 & 1,000 & .494 & .431 \\
\hline & Vp3 & .000 & .041 &,- 131 & .148 & .434 & .494 & 1,000 & .490 \\
\hline & Vp10 & -.142 &,- 021 &,- 059 & .062 & .388 & .431 & .490 & 1,000 \\
\hline
\end{tabular}


For testing the appropriateness of the factor model we used Bartlett's Test of Sphericity ( $\chi^{2}$ test) to test the null hypothesis that the variables are uncorrelated in the population. The observed significance level is .0000 (Neal, 2010). In our study, the null hypothesis, that the population matrix is an identity test, is rejected by Bartlett's Test of Sphericity. The approximate chi-square is 91,332 with 28 degrees of freedom, which is significant at 0.05 level (Fiugre 5). It is concluded that the strength of the relationship among variables is strong. The applicability of factor analysis was tested also using Kaiser-Meyer-Olkin Measure of Sampling Adequacy (KMO measure). The KMO measures the sampling adequacy which should be greater than 0.5 for a satisfactory factor analysis to proceed (Neal, $2010)$. In our study the value of KMO statistic $(0,618)$ is also large $(>0.5)$. Thus, factor analysis may be considered for analyzing the correlation matrix. In order to assess the reliability of compound scales (the extracted factors) the Cronbach Alpha Coefficient was calculated for each factor (Figure 6). The reliability coefficient $\alpha$ of 0,7 or higher is considered acceptable in most social science research situations (Malhotra, 2010). As indicated the results of analysis are close to satisfactory for all factors, where factors have Cronbach Alpha values from 0,603 to 0,744. These results indicate that the extracted factors appropriately characterize the dimensionality of the data.

Figure 5: Measures of Applicability

KhHO and Bartlett's Test ${ }^{a}$

\begin{tabular}{|c|c|c|}
\hline \multicolumn{2}{|c|}{ Kaiser-Meyer-Olkin Measure of Sampling Adequac) } & .618 \\
\hline \multirow{3}{*}{$\begin{array}{l}\text { Bartlett's Test of } \\
\text { Sphericity }\end{array}$} & Approx. Chi-Square & 91,332 \\
\hline & $\mathrm{df}$ & 28,000 \\
\hline & Sig. & 000 \\
\hline
\end{tabular}

a.Based on correlations

Figure 6: Reliability Statistics: Cronbach's Alpha

\begin{tabular}{|c|c|c|}
\hline $\begin{array}{l}\text { Reliability Statistics for } \\
\text { first factor: } \\
\text { Doing based experience }\end{array}$ & $\begin{array}{l}\text { Reliability Statistics for } \\
\text { second factor: } \\
\text { Visual based experience }\end{array}$ & $\begin{array}{l}\text { Reliability Statistics for } \\
\text { third factor: } \\
\text { Hearing based experience }\end{array}$ \\
\hline $\begin{array}{c}\text { Cronbach's } \\
\text { Alpha }\end{array}$ & $\begin{array}{c}\text { Cronbach's } \\
\text { Alpha }\end{array}$ & $\begin{array}{c}\text { Cronbach's } \\
\text { Alpha }\end{array}$ \\
\hline, 729 &, 744 & 603 \\
\hline
\end{tabular}

For the purpose of interpretation of results, each factor was composed of variables that loaded 0.40 or higher on the factor. The total variance explained statistics (Figure 7) displays the initial eigenvalues, extraction sums of squared loadings, and varimax rotation sums of squared loadings. In all, the three factors explained 48,658 percent of the total variance. According to eigenvalues rule ("greater-than-one rule", Neal, 2010) and scree plot (Figure 8) three factors were extracted and labelled as visual based learning experience (best explaining two variables Vp1, Vp6), hearing based learning experience (best explaining two variables Vp2, Vp7) and dong based learning experience (best explaining four variables $\mathrm{Vp} 8, \mathrm{Vp} 9, \mathrm{Vp} 3$ and $\mathrm{Vp} 10$ ) confirming our modified version of learning style theory. Variables defined by individual factors are indicated with red frames in Figure 8.

The rotated factor matrix contains the rotated factor loadings, which are the correlations between the variable and the factor. From output of our study we can see that rotated solutions resulted in extraction of three distinct factors, as they are explained above (Figure 8). 
Figure 7: Total Variance Explained Statistics

Total Variance Explained

\begin{tabular}{|c|c|c|c|c|c|c|c|c|c|c|}
\hline & \multirow[t]{2}{*}{ Factor } & \multicolumn{3}{|c|}{ Initial Eigenvalues ${ }^{a}$} & \multicolumn{3}{|c|}{ Extraction Sums of Squared Loadings } & \multicolumn{3}{|c|}{ Rotation Sums of Squared Loadings } \\
\hline & & Total & $\%$ of Variance & Cumulative $\%$ & Total & $\%$ of Variance & Cumulative $\%$ & Total & $\%$ of Variance & Cumulative $\%$ \\
\hline \multirow[t]{8}{*}{ Raw } & 1 & 2,244 & 34,898 & 34,898 & 1,720 & 26,744 & 26,744 & 1,708 & 26,561 & 26,561 \\
\hline & 2 & 1,168 & 18,163 & 53,061 &, 780 & 12,122 & 38,866 & .715 & 11,124 & 37,684 \\
\hline & 3 &, 992 & 15,419 & 68,480 &, 582 & 9,047 & 47,912 &, 658 & 10,228 & 47,912 \\
\hline & 4 &, 601 & 9,346 & 77,827 & & & & & & \\
\hline & 5 & .564 & 8,775 & 86,602 & & & & & & \\
\hline & 6 &, 390 & 6,059 & 92,660 & & & & & & \\
\hline & 7 &, 288 & 4,481 & 97,141 & & & & & & \\
\hline & 8 &, 184 & 2,859 & 100,000 & & & & & & \\
\hline \multirow[t]{8}{*}{ Rescaled } & 1 & 2,244 & 34,898 & 34,898 & 1,784 & 22,295 & 22,295 & 1,772 & 22,145 & 22,145 \\
\hline & 2 & 1,168 & 18,163 & 53,061 & 1,219 & 15,233 & 37,528 & 1,105 & 13,816 & 35,961 \\
\hline & 3 &, 992 & 15,419 & 68,480 &, 890 & 11,130 & 48,658 & 1,016 & 12,697 & 48,658 \\
\hline & 4 &, 601 & 9,346 & 77,827 & & & & & & \\
\hline & 5 &, 564 & 8,775 & 86,602 & & & & & & \\
\hline & 6 &, 390 & 6,059 & 92,660 & & & & & & \\
\hline & 7 & 288 & 4,481 & 97,141 & & & & & & \\
\hline & 8 &, 184 & 2,859 & 100,000 & & & & & & \\
\hline
\end{tabular}

Extraction Method: Principal Axis Factoring.

a.When analyzing a covariance matrix, the initial eigenvalues are the same across the raw and rescaled solution.

Figure 8: Rotated Factor Matrix and Scree Plot

Confirming the Applicability of the Experiential Based Learning Model

\begin{tabular}{|c|c|c|c|c|c|c|}
\hline \multicolumn{7}{|c|}{ Rotated Factor Matrix ${ }^{a}$} \\
\hline & \multicolumn{3}{|c|}{ Raw } & \multicolumn{3}{|c|}{ Rescaled } \\
\hline & \multicolumn{3}{|c|}{ Factor } & \multicolumn{3}{|c|}{ Factor } \\
\hline & 1 & 2 & 3 & 1 & 2 & 3 \\
\hline Vp1 &,- 053 &, 690 &, 000 &,- 069 &, 906 & .000 \\
\hline Vp6 &, 031 & .401 &, 065 & .033 & .426 &, 069 \\
\hline Vp2 &,- 072 &, 132 & .570 &,- 100 &, 183 & .790 \\
\hline Vp? & .169 &,- 032 & .559 & .180 &,- 034 & .597 \\
\hline Vp8 & .283 &,- 064 & .077 & .532 &,- 119 &, 144 \\
\hline Vp9 & .655 & .211 &, 091 & .649 &, 209 &, 090 \\
\hline Vp3 & .827 &, 048 &,- 030 & .760 &, 044 &,- 028 \\
\hline Vp10 & .692 &,- 094 &,- 030 & .664 &,- 090 &,- 029 \\
\hline
\end{tabular}

Extraction Method: Principal Axis Factoring.

Rotation Method: Varimax with Kaiser Normalization.

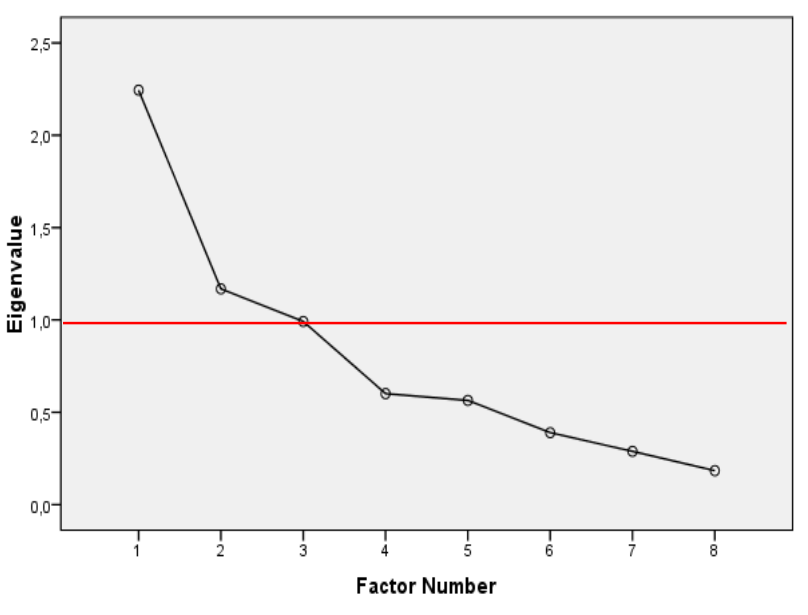

a. Rotation converged in 4 iterations. 


\section{DISCUSSION}

“One goal of management education is to help students organize experience in meaningful ways” (Kayes, 2007)

A study was undertaken to determine the factors underlying student's perceptions of experiential learning styles in order to develop appropriate strategies for improving experiential learning methods and management implications at FELU. The research confirmed the results through sequential qualitative meta-analysis and quantitative factor analysis. According to the quantitative research process we can confirm our research hypothesis that matching students' experiential learning-style preferences, consisting of three extracted factors (visual based learning experience, hearing based learning experience, and doing based learning experience), with complementary course syllabus improve management education, academic achievements and student's attitudes toward learning. We have utilized Principal Axis Factoring method as an efficient tool not only to discovering key factors of the modified experiential learning method used, but also for highlighting the relationship between theory and implications for management education. The secondary objective of the study was to develop valid and reliable research questionnaire for further research. It is our hope that future research will lead to further evaluation and improvements of developed research instrument for experiential learning practices. The questionnaire was developed to get the first of experiential learning styles in national higher education system and was significantly influenced by the small sample size and its focus on probing the validity of chosen theory.

Results suggest that the mission of higher management education is to create and disseminate knowledge to enable students' successful entry into the business world and offer a rewarding investment opportunity to the community. The development of these new skills and knowledge requires a variety of experiential teaching methods and learning strategies in order to match students' learning style preferences. Therefore, management in higher education need awareness of development experiential based learning style methods in order to utilize effective and efficient teaching and pedagogical strategies. Recognizing students' learning styles allows educators to effectively lecture to a diverse population of students with different learning style preferences. The fit of particular method in a specific course with the overall syllabus, the goals of the modules, the resources available to the instructors, and the individual learner's need and willingness for a particular method, all play an important part in the choice to adopt new learning methods, and the effective implementation in Slovenian higher education. Researchers should continue to carry out instruments designed to measure experiential learning styles and methods. A better understanding of experiential based learning philosophy will allow management educators in higher educational system to better match instructional goals with appropriate experiential learning methods and tools. The research should explore the role of management educators in developing experiential learning practices according to extracted factors (Figure 9). The logic of experiential learning suggests that students will become more motivated to learn by experiencing and knowing more about their own strengths and weaknesses as learners. Consequently, if lectures can respond to individuals' learning style preferences, then the achievement rate is likely to rise and experiential "learning to learn" skills and competencies of students may provide the foundation for the experiential learning concept.

Figure 9: Developing Experiential Learning Practices

\begin{tabular}{|c|c|}
\hline \multicolumn{2}{|r|}{ Management Education Implications: The Results and Implications for Each Factor } \\
\hline $\begin{array}{l}\text { Implications for factor } 1: \\
\text { Visual based learning } \\
\text { experience }\end{array}$ & $\begin{array}{l}\text { - Learners in experiential based process collaborate in small groups to share their perspectives, } \\
\text { questions, visual insights with the intent to learn from one another about the presenting } \\
\text { problem and possible solutions. } \\
\text { - The learning materials are ideally tailored to the experiential learning process, with resources } \\
\text { and support to gain access to special tacit knowledge and disciplinary theory. }\end{array}$ \\
\hline $\begin{array}{l}\text { Implications for factor } 2 \text { : } \\
\text { Hearing based learning } \\
\text { experience }\end{array}$ & $\begin{array}{l}\text { - Participants are asked to bring problems and their experience to the learning process, to } \\
\text { describe the problem with which they wish to work in the group or individually. } \\
\text { - Group work in experiential learning process provides space for interpersonal communication, } \\
\text { interaction, and experiential dynamics among participants. }\end{array}$ \\
\hline $\begin{array}{l}\text { Implications for factor } 3: \\
\text { Doing based learning } \\
\text { experience }\end{array}$ & $\begin{array}{l}\text { - The approach of experiential learning is best suited to the case-study method of teaching. } \\
\text { - The complex learning problems present the learners, both individuals and in groups, with } \\
\text { challenges about their own resourcefulness, capacity to think creatively and critically, and their } \\
\text { personal organization for integrating new information. } \\
\text { - Forming, storming, and norming in groups have to be anticipated and managed until desired } \\
\text { kinaesthetic performance emerges. }\end{array}$ \\
\hline
\end{tabular}


The value of this research lies in helping to improve an experiential learning styles research instruments with implications for higher management education system and institutions. The process of changing from traditional teaching method to experiential methods is not easy for the educational institution. Institutional forces make change challenging, even when university signals that it wants to change. The available management education literature does not address sufficiently the choice of experiential learning methods in practice. The choice of a method often depends on institutional traditions, professional interests and educational system. The implications for management indicate that instead of traditional learning styles strategies management educators should rather implement problem-based learning methods. The approach of problem-based learning methods is best suited to the case-study method of teaching. Our study shows that the differences between experiential methods are important to acknowledge because different methods address different needs, and also the demands and constraints of the management education. Being an effective lecturer, implies matching individual learning style preferences among students with course syllabus and teaching strategies based on experiential learning platform. An extended study based on this research would be recommended with a larger sample of students in order to accumulate more comprehensive conclusions and broaden implications for management education.

\section{CONCLUSION}

“Experiential learning is learning approach that can reveal the educational institution” (Reynolds \& Vince, 2007)

This paper advances the experiential learning style theory and practice in higher education in Slovenia, by uncovering the critical role played by lectures and management. The literature on experiential learning has had a revival during last years. Recent studies indicate that lecturers in higher education need an awareness of the experiential learning style preferences of students in order to develop and utilize effective and efficient teaching and pedagogical strategies and methods. The research aim of this study was to evaluate the implications of tested theory with factor analysis for management implications within higher education institution in Slovenia. Additionally, in our study we analyzed the experiential learning practices at University of Ljubljana, Faculty of Economics in Slovenia in order to develop appropriate teaching and pedagogical strategies for improving higher management education practices. In the theoretical part of the study the sequential meta-analysis method was used to overview the literature on experiential learning styles and methods. In the empirical part of the study the Principal Axis Factoring, was employed. By running the analysis, we tested the main hypothesis to uncover the factors of students' learning-style preferences with the aim to accomplish higher management education model, academic achievements and student's attitudes toward learning.

According to the results of the study, there is a trend in higher education to orient students effectively toward experiential learning process, to prepare, train, and support them to learn effectively in teams, and to identify and fulfill their individual learning needs. The implications for pedagogy and management indicate that instead of classical learning styles strategies, adapting content to the learner, management educators should rather implement experimental learning processes and strategies. The implications regarding the learning strategies implementation in management education suggest that students who are aware of a range of experiential learning strategies are more likely to select the correct one for a particular task. Lecturers in higher education need an awareness of the learning style preferences of students in order to develop and utilize effective and efficient experiential learning strategies and methods. We can summarize that awareness of experiential earning styles may help students to adapt better to different situations. The final results suggest that in higher education in Slovenia, according to FELU case, the experiential learning style theory should be implemented in higher management education model for improving academic excellence and student's attitudes toward learning.

\section{AUTHOR INFORMATION}

Sandra Penger, Ph.D., is assistant professor the Department of Management and Organization at the Faculty of Economics, University of Ljubljana (http://www.ef.uni-lj.si/en/). Her research interests are in economics of education, learning styles, authentic leadership, positive organizational behavior, learning organization and new public management. She attended many international conferences, where she presented papers in her research areas and published several articles in Slovene, European, and US journals. More information at http://www.ef.unilj.si/pedagogi/pedagog.asp?id=301, or via e-mail: sandra.penger@ef.uni-lj.si. 
Jana Žnidaršič, Ph.D., is assistant professor the Department of Management and Organization at the Faculty of Economics, University of Ljubljana (http://www.ef.uni-lj.si/en/). Her research interests are in age management, business communication, economics of education, management process, organizational behavior, learning organization and new public management. She attended many international conferences, where she presented papers in her research areas and published several articles in Slovene, European, and US journals. More information at http://www.ef.uni-lj.si/pedagogi/pedagog.asp?id=356; or via e-mail: jana.znidarsic@ef.uni-lj.si.

Vlado Dimovski, Ph.D., is full professor at the Department of Management and Organization at the Faculty of Economics, University of Ljubljana (http://www.ef.uni-lj.si/en/). His research interests are in organizational learning, organizational social networks, authentic leadership, age management, and learning organization. His studies on knowledge management and organizational learning culture, using structural model and meta-analysis techniques for performance improvement relating to the Slovenian and Eastern Europe data assessment, are published in SCIE journals in the field of management, information technology, industrial and organizational behavior. More information at http://www.ef.uni-lj.si/pedagogi/pedagog.asp?id=65; or via e-mail: vlado.dimovski@ef.uni-lj.si.

\section{REFERENCES}

1. Alban-Metcalfe, J. (2002). Attention Deficit/Hyperactivity Disorder Type Behaviors among Undergraduates and their Relation to Learning Style. Research in Education, 68, 89-109.

2. Alkhasawneh, I. M, Mrayyan, M. T., Docherty, C., Alashram, S., \& Yousef, H. Y. (2008). Problem Based Learning: Assessing Students' Learning Preferences Using Vark. Nurse Education Today, 28(5), 572-579.

3. Allinson, C. W., \& Hayes, J. (1990). Validity of the Learning Styles Questionnaire. Psychological Report, 67, 859-866.

4. Argyris, C. (2007). Double-Loop Learning in Classroom Setting. In: M. Reynolds, \& R. Vince (Eds.), Handbook of Experiential Learning \& Management Education. Oxford, Oxford University Press.

5. Armstrong, S., \& Mahmud, A. (2008). Experiential Learning and the Acquisition of Managerial Tacit Knowledge. Academy of Management Journal, 7(2), 189-208.

6. Arnold, N., Paulus, T. (2010). Using a Social Networking Site for Experiential Learning: Appropriating, Lurking, Modeling and Community Building. The Internet and Higher Education, In Press, Accepted Manuscript, Available online 26 April 2010.

7. Brewerton, P., \& Millward, L., (2001). Organizational Research Methods. London: Sage Publications.

8. Campo, P. G, Gómez, F. G., Dimovski, V., \& Škerlavaj, M. (2008). Exploratory Study of Organizational Learning Network within Spanish High-Tech Company. Zb. rad. Ekon. Fak. Rijeka, 26 (2), 257-277.

9. Champoux, J. E. (2007). Experiential Learning in the On-Line Environment: Enhancing On-Line Teaching and Learning. In: M. Reynolds, \& R. Vince (Eds.), Handbook of Experiential Learning \& Management Education. Oxford, Oxford University Press.

10. Coffield, F., Moseley, D., Hall, E., \& Eclestone, K. (2004). Learning Styles and Pedagogy in Post-16 Learning: A Systematic and Critical Review. Wiltshire: Learning and Skills Research Centre.

11. Constantinidou, F., \& Baker, S. (2002). Stimulus Modality and Verbal Learning Performance in Normal Aging. Brain and Language, 82(3), 296-311.

12. Coven, R., \& Kazamias, A.M. (2009). International handbook of Comparative Education. London: Springer Science.

13. Cuthbert, P. F. (2005). The Student Learning Process: Learning Styles or Learning Approaches? Teaching in Higher Education, 10(2), 235- 249.

14. Dart, B. C., Burnett, P. C., Puride, N., Boulton-Lewis, G., Campbell, J., \& Smith, D. (2000). Students' Conceptions of Learning, the Classroom Environment, and Approaches to Learning. The Journal of Educational Research, 93(4), 262-270.

15. Demirbas, O. O., \& Demirkan, H. (2007). Learning Styles of Design Students and the Relationship of Academic Performance and Gender in Design Education. Learning and Instructions, 17, 345-359.

16. Dimovski, V., \& Škerlavaj, M. (2004). Organizational Learning and Information Communication Technologies: A Promising Link. Journal of Economics and Business, 22(1), 7-21. 
17. Dimovski, V., Škerlavaj, M., Kimman, M., \& Hernaus, T. (2008). Comparative Analysis of the Organizational Learning Process in Slovenia, Croatia, and Malaysia. Expert Systems with Applications, 34 (4), 3063-3070.

18. Duff, A., \& Duffy, T. (2002). Psychometric Properties of Honey and Mumford's Learning Style Questionnaire. Personality and Individual Differences, 22, 147-163.

19. Duff, A., Dobie, A., \& Guo, X. (2008). The Influence of Business Case Studies and Learning Styles in an Accounting Course: A Comment. Accounting Education, 17(2), 129-144.

20. Dunn, R. (2001). Learning Style: State of the Science. Theory into Practice, 13(1), 10-19.

21. Dunn, R. (2003). The Dunn and Dunn Learning Style Model: Theoretical Cornerstone, Research and Practical Applications. In S. Armstrong, \& M. Graff (Eds.), Bringing Theory and Practice, Proceedings of the 8th Annual European Learning Styles Information Network Conference. Hull: University of Hull.

22. Dunn, R., \& Griggs, S. (2003). Synthesis of the Dunn and Dunn Learning Style Model Research: Who, What, When, Where, and What? New York: St. Johns' University Press.

23. Ellinger, A. D., \& Doctoral Students. (2007). Experiencing Scholarly Writing through a Collaborative Course Project. In M. Reynolds, \& R. Vince (Eds.), Handbook of Experiential Learning \& Management Education. Oxford, Oxford University Press.

24. Entwistle, N. J. (1998). Improving Teaching through Research on Student Learning. In J. J. F. Forrest (Ed.), University teaching: International Perspectives. New York: Gerland.

25. Garcia, P., Amandi, A., Schiaffino, S., \& Campo, M. (2007). Evaluating Bayesian Networks' Precision for Detecting Students' Learning Styles. Computers \& Education, 49, 794-808.

26. Herbert, A., \& Stenfors, S. (2007). Choosing Experiential Methods for Management Education: The Fit of Action Learning and Problem-Based Learning. In M. Reynolds, \& R. Vince (Eds.), Handbook of Experiential Learning \& Management Education. Oxford, Oxford University Press.

27. Honey, P., \& Mumford, A. (1992). The Manual of Learning Styles. Maidenhead: Peter Honey Publications.

28. Hyde, P. (2007). Integrating Experiential Learning through Live Projects. In M. Reynolds, \& R. Vince (Eds.), Handbook of Experiential Learning \& Management Education. Oxford, Oxford University Press.

29. Kappe, F.R., Boekholt, L., den Rooyen, C., \& Van der Flier H. (2009). A Predictive Validity Study of The Learning Style Questionnaire using Multiple, Specific Learning Criteria. Learning and Individual Differences, 19(4), 464-467.

30. Kayes, A. B. (2007). Power and Experience: Emancipation through Guided Leadership Narratives. In M. Reynolds, \& R. Vince (Eds.), Handbook of Experiential Learning \& Management Education. Oxford, Oxford University Press.

31. Kayes, D. C. (2007). Institutional Barriers to Experiential Learning Revisited. In M. Reynolds, \& R. Vince (Eds.), Handbook of Experiential Learning \& Management Education. Oxford, Oxford University Press.

32. Kayes, D. D. (2002). Experiential Learning Theory and its Critics: Preserving the Role Of Experience in Management Learning and Education. Academy of Management Learning and Education, 1(2), 137-149.

33. Koçakoğlu, M., Türkmen, L., Solak, K. (2010). Motivational Styles in Problem-Based Learning. Procedia Social and Behavioral Sciences, 2, 615-619.

34. Kolb, D. A. (1976). Learning Style Inventory: Technical Manual. Boston: McBer \& Company.

35. Kolb, D. A. (1984). Experiential Learning: Experience as the Source of Learning and Development. NJ: Prentice Hall.

36. Kolb, D. A. (1999). The Kolb's Learning Styles Inventory. Boston: Hay Group.

37. Lhori-Posey, B. (2003). Determining Learning Styles of Students. Nurse Educator, 28(2), 54.

38. Li, Y. S, Chen, P. S., \& Tsai, S. J. (2008). A Comparison of the Learning Styles among Different Nursing Programs in Taiwan: Implications for Nursing Education. Nurse Education Today, 28, 70-76.

39. Loo, R. (2004). Kolb's Learning Styles and Learning Preferences: Is There A Linkage? Educational Psychology, 24(1), 99-108.

40. Malhotra, N.K. (2010). Marketing Research: An Applied Orientation. New Jersey: Pearson Education.

41. Metallidou, P., \& Platsidou, M. (2008). Kolb's Learning Style Inventory: Validity Issues and Relations with Metacognitive Knowledge about Problem-Solving Strategies. Learning and Individual Differences, 18(1), 114-119.

42. Neal, W.D. (2010): Factor analysis. In N.K. Malhotra (Ed.), Marketing Research: An applied orientation (pp. 634-660). New Jersey, Pearson Education. 
43. Ortigosa, A., Paredes, P., \& Rodriguez, P. (2010). AH-questionnaire: An Adaptive Hierarchical Questionnaire for Learning Styles. Computers \& Education, 54(4), 999-1005.

44. Penger, S., \& Tekavčič, M., (2009). Testing Dunn \& Dunn's and Honey \& Mumford's Learning Style Theories: The Case of the Slovenian Higher Eucation System. Management (Split), 14(2), 1-20.

45. Peters, D., Jones, G., \& Peters, J. (2008). Preferred 'Learning Styles' in Students Studying Sports-Related Programmers in Higher Education in the United Kingdom. Studies in Higher Education, 3(2), $155-166$.

46. Peterson, E.R., Rayner, S.G., \& Armstrong, S.J. (2009). Researching the Psychology of Cognitive Style and Learning Style: Is there really a Future? Learning and Individual Differences, 16(4), 518-523.

47. Pretz, J.E., Totz, K.S., \& Kaufman, S.B. (2010). The Effects of Mood, Cognitive Style, and Cognitive Ability on Implicit Learning. Learning and Individual Differences, 20(3), 215-219.

48. Rourke, B., Ahmad S., Collins, D., Hayman-Abello, B., Hayman-Abello, S., \& Warriner, E. (2002). Child Clinical/Pediatric Neuropsychology: Some Recent Advances. Annual Review of Psychology, 53, 309339.

49. Sievers, B. (2007). Pictures from below the Surface of the University: The Social Photo-Matrix as a Method for Understanding Organizations in Depth. In M. Reynolds, \& R. Vince (Eds.), Handbook of Experiential Learning \& Management Education. Oxford, Oxford University Press.

50. $\quad$ Škerlavaj, M., \& Dimovski, V. (2006a). Social Network Approach to Organizational Learning. Journal of Applied Business Research, 22(2), 89-97.

51. S Škerlavaj, M., \& Dimovski, V. (2006b). Influence of Organizational Learning on Organizational Performance from Employee Perspective: The Case of Slovenia. Management, 11, 75-90.

52. Škkerlavaj, M., \& Dimovski, V. (2007). Towards Network Perspective of Intra-Organizational Learning: Bridging the Gap between Acquisition and Participation Perspective. Interdisciplinary Journal of Information, Knowledge and Management, 2, 43-58.

53. Š́kerlavaj, M., Dimovski, V., \& Desouza, K. (2010a). Patterns and Structures of Intra-Organizational Learning Networks Within a Knowledge-Intensive Organization. Journal of Information Technology.

54. S Škerlavaj, M., Dimovski, V., Mrvar, A., \& Pahor, M. (2010b) Intra-Organizational Learning Networks within Knowledge-Intensive Learning Environments. Interactive Learning Environments, 18(1), 39-63.

55. $\quad$ Škerlavaj, M., Dimovski, V., Mrvar, A., \& Pahor. M. (2008). Intra-Organizational Learning Network within Knowledge-Intensive Learning Environments. Interactive learning environments, 1-24.

56. ŠSkerlavaj, M., Indihar Štemberger, M., Škrinjar, R., \& Dimovski, V. (2007). Organizational Learning Culture - the Missing Link between Business Process Change and Organizational Performance. International Journal of Production Economics, 106, 346-367.

57. Š́kerlavaj, M., Song, J.H., \& Lee, Y. (2010). Organizational Learning Culture, Innovative Culture and Innovations in South Korean Firms. Expert Systems with Applications, 37(9), 6390-6403.

58. Tseng, J. C. R., Chu, H. C., Hwang, G. J., \& Tsai, C.C. (2008). Development of an Adaptive Learning System with Two Sources of Personalization Information. Computers \& Education, 51(2), 776-786.

59. Welsh, M.A., Dehler, G. E., \& Murray, D. L. (2007). Learning About and Through Aesthetic Experience: Understanding the Power of Experience-Based Education. In M. Reynolds, \& R. Vince (Eds.), Handbook of Experiential Learning \& Management Education. Oxford, Oxford University Press.

60. Young, T. (2010). How Valid and Useful is the Notion of Learning Style? A Multicultural Investigation. Procedia - Social and Behavioral Sciences, 2(2), 427-433.

61. Zagoršek, H., Dimovski., V., \& Škerlavaj, M. (2009). Transactional and Transformational Leadership Impacts on Organizational Learning. Journal for East European Management Studies, 14(2), 144-165. 